\title{
ECOLOGY OF SOME MARINE LAGOONS ALONG THE EAST-COAST OF INDIA WITH SPECIAL REFERENCE TO THE MANAGEMENT AND UTILISATION OF THEIR RESOURCES
}

\author{
by \\ A.G.K. MENON ${ }^{1)}$ and K. RAMAN ${ }^{2)}$
}

INTRODUCTION

The marine lagoons along the east coast of India such as the Chilka-lake in Orissa State, the Pulicat and the Ennore lakes near Madras, Silvatturai lagoon in Tuticorin, and the Mandapam lagoon in Ramanathapuram are shallow, vast sheets of saline water whose physical and chemical characteristics are quite different from the backwaters of the west coast and constitute distinct categories of biological environment. The main characteristic feature of these lagoons is that they are connected to the sea by a narrow mouth which is closed by a sand bar for varying periods of the year. One or more seasonal rivers open into some of these lagoons and flood them during the monsoon. The land run-off during monsoon is the only source of freshwater for others. The bar-mouth connection with the sea is opened by the thrust of the flood waters aided in some cases by human effort. This opening operates for a few months between November - December and June - July or throughout during some years following heavy monsoon. The closure occurs by general silting and formation of a sand bar.

The productive potentiality of these lagoons have been brought to the attention of the public from time to time by several workers (СНACKO et al 1953, TAMPI 1959). The continued failure of monsoon during the past few years, the construction of dams and the drying up of the rivers opening into the lagoons and increased silting up have affected the opening and closure of the bar-mouth and consequently the general ecology of the lagoons. The ecological peculiarities of the lagoons as typified by the Pulicat lake is discussed in this paper and the means of keeping the bar mouth permanently open in order to create a continuous circulation of sea water in the lake are suggested for the proper management and utilisation of their resources.

1) Zoological Survey of India, Madras.

2) Pulicat Lake Unit of Central Inland Fisheries Research Institute, Madras. 


\section{A.G.K. MENON \& K. RAMAN}

\section{MORPHOMETRY OF PULICAT LAKE}

The Pulicat lake is the largest of the lagoons in the south-east coast of India having a water spread of about $350 \mathrm{~km}^{2}$. It lies mainly in the Nellore district of Andhra Pradesh with a little portion in the Chingleput district of Tamil Nadu between latitudes $13^{\circ} 24^{\prime}$ and $13^{\circ} 47^{\prime} \mathrm{N}$, and longitudes $80^{\circ} 2^{\prime}$ and $80^{\circ} 16^{\prime} \mathrm{E}$. In the middle part of the lake there are two islands, namely Venadu and Irakkam. The lake is shallow to the north and east of Irakkam, the depth being seldom more than $1 \mathrm{~m}$ during summer season. The deepest portion is between Karimanal Kuppam and Pulicat with a water column of about 3 to $5 \mathrm{~m}$. The opening into the sea is at the narrow southern end with the main body extending north and north-west, parallel to the sea-coast. The lake mouth is very shallow and reaches a maximum width of about 200 m.

\section{HYDROLOGICAL FEATURES}

A small seasonal rivulet (Kalangi) drains into the lake at its north-west and another (Arani River) on the south-west. After the construction of dams on the Arani and other small rivulets at their upper reaches the quantum of freshwater flow into the lake has been drastically reduced resulting in the closure of the bar for long periods. Normally the freshwater incursion into the lake is thus not much except due to heavy rains during the monsoon. During the rainy season when the lake gets filled up with freshwater the closed mouth is forced open naturally and/or with manual effort. The tidal amplitude is, however, very low even at the time when the mouth remains open and it is felt upto only to a distance of about 7 to $8 \mathrm{~km}$ to the interior, the northern expanse not getting much sea water influence. In summer months the northern areas become hypersaline due to evaporation and lack of influx of water (SREENIVASAN \& PILLAi 1972). The annual closure of lake mouth also exerts a profound influence on the hydrology of the lake.

The Buckingham canal, a man-made navigational canal traverses the entire length of the spit formation ${ }^{1)}$ (Sriharikota spit) separating the lake

l) Spits or ridges of sand, shingle and other sediments raising above high tide and forming bars separated from the mainlands enclose shallow portions of the sea which ultimately become lagoons. Spits are formed mainly by waves out of the sediments eroded from the submarine floor sea-ward of the bar. Another source of spit formation is due to the sand and sediments being carried along the coast by waves in what is known as long-shore drift. The spit of the east coast are invariably orientated to north or north east that their origin due to long shore drift from south and south-west under the influence of the south-west monsoon is unmistakable (vide Coastal geomorphology of India by AHMAD, E. 1972). 
ECOLOGY OF SOME MARINE LAGOONS

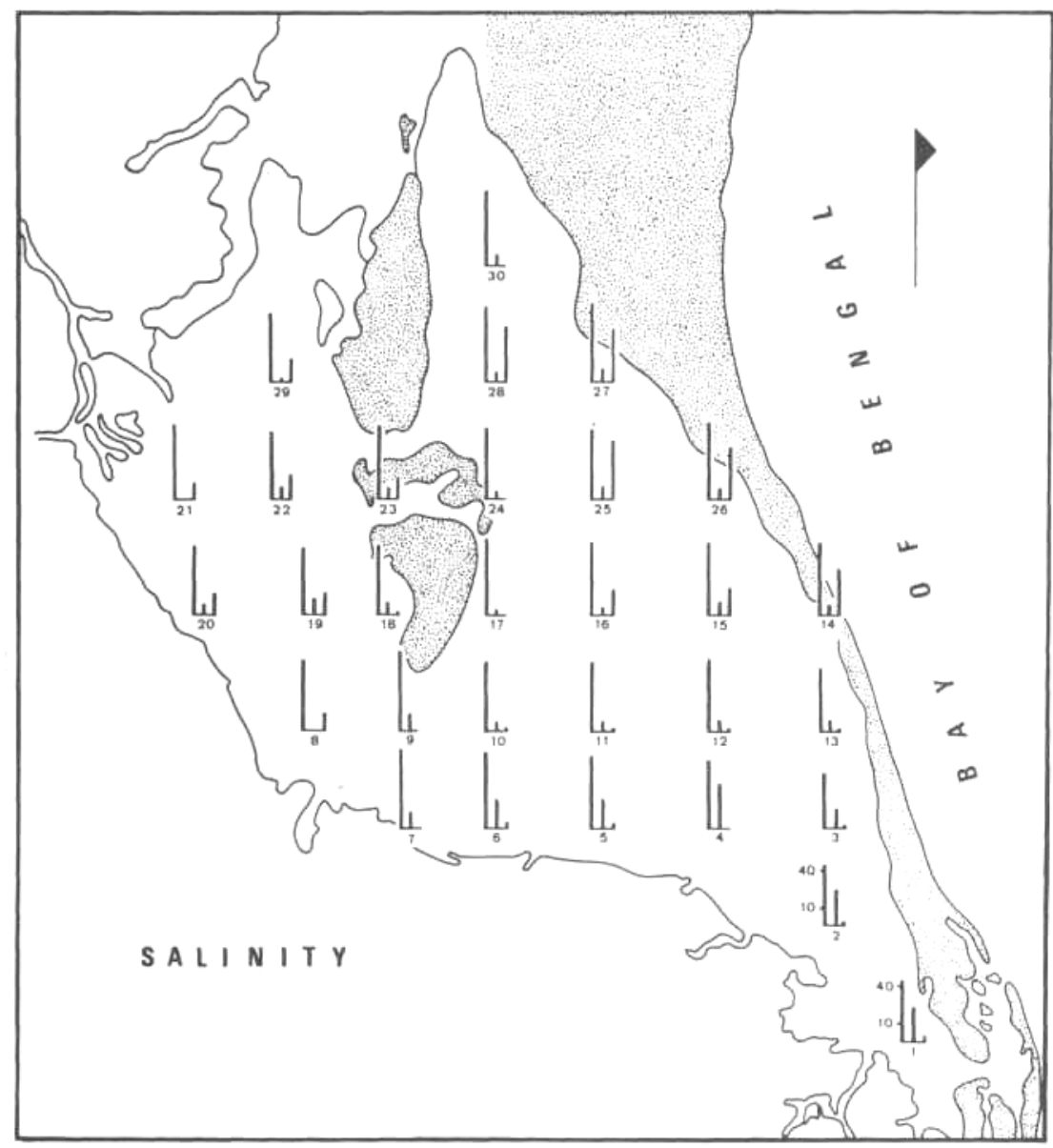

Fig. 1. Map of Pulicat lake showing surface salinity values during pre-monsoon, monsoon and post-monsoon at different stations. 


\section{A.G.K. MENON \& K. RAMAN}

from the sea. About $70 \mathrm{~km}$ north of Pulicat and on the east of Buckingham canal there is a wide shallow opening into the sea near Duggirajapatnam which remains open during a part of the year. However, due to the steep gradient from the south, the effect of this mouth is not felt much into the canal or the connected water bodies. South of this opening, there is another smaller seasonal connection with the sea at Kodimunai. During the north-east monsoon all the shallow areas in north get inundated and become a single sheet of water contiguous with the southern parts of the lake and the Buckingham canal.

\section{METHOD OF COLLECTIONS AND ANALYSIS}

The hydrological parameters along with plankton, benthic flora and fauna were collected from the whole lake between June 1972 and May 1973 by the junior author and his colleagues K.V. RAMAKRISHNA, S. RADHAKRISHNAN and G.R.M. RAO of the Pulicat Lake Unit of the Central Inland Fisheries Research Institute, Madras. Thirty sampling stations were selected along the entire longitudinal and transverse transects and observations on different parameters from all the stations were made once during the different seasons of the year, namely pre-monsoon (June - September), monsoon (October - January) and postmonsoon (February - May). Temperature. - The surface temperature recorded under clear weather conditions ranged between 28.6 and $35.0^{\circ} \mathrm{C}$ during pre-monsoon, 24.6 and $30.6^{\circ} \mathrm{C}$ during monsoon and between 26.1 and $31.7^{\circ} \mathrm{C}$ during post-monsoon. Salinity. - The salinity values during different months of the year as well as samples from different regions in the lagoon at the same time vary considerably depending on the time of opening of the sand bar and the tidal amplitude. During the time of stagnation in pre-monsoon the salinity ranging from 37.5 to $57.0 \mathrm{ppt}$ (average $50.5 \mathrm{ppt}$ ) has been recorded, the average salinity being at the lowest in the southern zone (46.75 ppt) (stations 1-7) gradually increasing towards middle zone (51.04 ppt) (stations 8-20) and reaching the maximum in the northern zone (52.0 ppt) (stations 21 -30). In monsoon the salinity ranging from $3.00 \mathrm{ppt}$ and $23.0 \mathrm{ppt}$ (average 8.90 ppt) have been recorded with a reverse gradient showing a fall in salinity from southern zone (average $17.57 \mathrm{ppt}$ ) to middle (5.81 ppt) and northern zone (5.93 ppt). In the post-monsoon season the salinity gradient reversed again to the pre-monsoon pattern showing a gradual increase from southern to the northern zone though the values ranged from 0.7 ppt to 40.0 ppt (average $11.24 \mathrm{ppt}$ ). 


\section{ECOLOGY OF SOME MARINE LAGOONS}

Dissolved oxygen. - The level of oxygen does not show any abnormal decrease at any time of the year though the level was low during pre-monsoon $(2.0-7.6 \mathrm{ppm})$ and moderately high during monsoon (3.8 - $11.6 \mathrm{ppm})$ and post-monsoon $(4.8-9.4 \mathrm{ppm})$ showing a gradual increase from pre-monsoon (average $5.0 \mathrm{ppm}$ ) to post-monsoon (average $6.8 \mathrm{ppm}$ ) through monsoon (average $6.5 \mathrm{ppm}$ ).

Plankton. - Bacillariophyceae (Navicula, Cymbella, Gyrosigma, Pleurosigma, Nitzschia, Fragilaria), Dinophyceae (Ceratium, Dinophrys), Myxophyceae (Oscillatoria), Rotifera (Brachionus, Pedalion, Conochilus) and Copepoda (Oithona, Paracalanus, Eucalanus, Acartia, Diaptomus, and Pseudodiapto-mus) along with larval forms of molluscs, polychaetes and nauplii and ascidian tadpoles constituted the prominent items of the plankton throughout the year. The density of plankton (in thousands/haul) ranged between 0.7 and 160.0 during pre-monsoon, 4.0 and 210.0 in monsoon and 9.0 and 650.0 in postmonsoon. Zooplankton was dominant during the post-monsoon, whereas during the premonsoon phytoplankton bloom was more prominent in all the zones of the lake. During monsoon, however, the phytoplankton bloom dominated only in the southern zone. Benthos. - The nature of the bottom of the lake differs at the different zones: zone 1 is characterised by predominance of sand in the substratum with little admixture of mud; zone 2 has sand and mud in equal proportions with patches of weeds; and zone 3 is entirely muddy.

Flora. - The bottom macrophytes consists mainly of rooted submerged plants like Halophila ovalis and Cymodocea isoetifolia and filamentous algae such as Chaetomorpha spp., Entermorpha spp., Ulva spp., Cladophora spp., and Acetabularia spp. A few red algae like Polysiphonia spp., Hypnea spp., and Gracilaria spp., are also present. They are confined to the shallow areas where the depth is less than a metre around the islands and the perimeter of the lake, forming patches of varying densities. The number of the bottom flora $/ \mathrm{m}^{2}$ ranged between 125 and 3250 during pre-monsoon, 387 and 900 in monsoon and 37 and 1305 in post-monsoon.

Fauna. - Polychaetes, tanaids, amphipods, and molluscs form the most important constituents; sea anemones, nematodes, chironomid larvae, miscellaneous crustaceans, and fish form the minor constituents. Almost all the groups are present in all the seasons except chironomid larvae which abound only during monsoon. Seasonwise, monsoon was found to be most productive (average $2100 / \mathrm{m}^{2}$ ) followed by post-monsoon (average $1761 / \mathrm{m}^{2}$ ) and pre-monsoon (average $204 / \mathrm{m}^{2}$ ). Zonewise, the southern zone was found to be the most productive (average $1410 / \mathrm{m}^{2}$ ) followed by middle 


\section{A.G.K. MENON \& K. RAMAN}

(average $1,384 / \mathrm{m}^{2}$ ) and northern (average $1,115 / \mathrm{m}^{2}$ ). Molluscs and poly-chaetes were responsible for the maximum production in southern zone whereas in the middle zone amphipods, molluscs and polychaetes formed the important groups in the order of abundance. In the northern zone amphipods were in maximum quantities followed by molluscs and tanaids.

\section{MANAGEMENT AND UTILISATION}

The biological conditions in the lake are largely dependent on the physical and chemical characteristics of the area. The fluctuation in water temperature during different seasons was somewhat similar and maximum and minimum differing only by about $6.0^{\circ} \mathrm{C}$. However, the lake attains hyper-saline conditions during pre-monsoon especially in the northern sector. This is mainly due to evaporation, shallowness, lack of freshwater and sea influence as well as the presence of salt impregnated marshy areas of the north (RAO 1971). During these periods in the northern sector the fish population, benthic fauna and plankton are comparatively poor. The growth of bottom flora alone does not seem to be affected by the hyper-saline conditions indicating their wide range of tolerance to salinity. The oxygen level in the lake throughout the year is congenial for life.

There are two phytoplanktonic maxima during pre-monsoon and monsoon. The zooplankters especially the larval forms usually follow the phytoplanktonic maxima which might be responsible for the rapid reduction of phytoplankton in the post-monsoon period. At the end of the monsoon season when the bar-mouth opens numerous organisms that enter the lake form the main food of higher animals in the lake. The peculiar physiological conditions created by the hyper-saline nature especially of the middle and the northern zones of the lake permit only highly euryhyline species to thrive in the lake. The annual landing of fishes including prawn comes to about 1,200 tonnes. Prawns Penaeus indicus, $P$. monodon, $P$. semisulatus, Metapenaeus dobsoni, M. monoceros, $M$. burkenroadi and $M$. affinis, constitute the prawn fishery. $P$. indicus usually forming about $45 \%$ of the prawn catch. Mullets (Mugil cephalus, Liza parsia, L. macrolepis, and Vagamugil cunnesius) contribute to the major portion of the fisherman's catches throughout the year. Perches (Sillago sihama, Genes oyena, G. filamentosus, Mylio berda, Siganus canaliculatus, and Lates calcarifer), clupeids (Nematolosa nasus, Thrissocles spp., Flops saurus, Chanos chanos, and Megalops cyprinoides), catfishes (Plotosus canius, Tachysurus spp., Mystus gulio) and crabs (Scylla serrata and Portunnus pelagicus) are also caught. 


\section{ECOLOGY OF SOME MARINE LAGOONS}

Since the amount of fish available in the lake depends largely on the number entering from the sea in their post-larval and juvenile stages and not of an autochthonous population, the time of the opening of the sand bar and the satisfactory tidal flow from the sea are of great importance. A continuous influx from the sea and thereby the prevention of excessive fluctuations in the physico-chemical conditions of the lake further help to improve the general ecology of the lake. The present practice of operating fixed nets like stake-nets during high tide virtually choking the lake mouth and filtering away all the fish and prawn irrespective of the size is highly detrimental and should be discouraged by proper legislation.

The continuous failure of monsoon and the drying up of the rivulets opening into the lake have contributed to the closure of the lake mouth since 1971, the duration of closure gradually increasing from two months in 1971 to almost seven months in 1975, probably foreshadowing a complete closure in the near future if the present conditions continue. The effects of human interference such as construction of a navigational canal cutting through most of these lagoons, keeping the bar-mouth open mechanically by dredging in the case of Ennore estuary for drawing of large quantities of water for cooling the thermal plant, pollution by sewage and industrial wastes and destructive fishing especially during the premonsoon shrinkage of the water level when the fishes retreat to the deeper portions etc. have brought about further deterioration of the lagoons on the south-east coast of India.

Through mechanical means the bar-mouth can be kept permanently open but it will not improve the ecology of the lagoon. The silt generated in the process of dredging will increase the turbidity of water and make the habitat unsuitable for fish and other organisms. It would be possible to establish a continuous connection with the sea by constructing groin walls to prevent the littoral drift from choking the bar-mouth after it is deepened by dredging. This is however, a costly engineering operation but if it is implimented it would restore the ecological conditions of the lake to normalcy.

For the proper management of the lagons it is, therefore, imperative to consider the lagoon and. the rivulets that open into it as a complete ecosystem and only by improving the rivulets and channels the bar-mouth can be kept permanently open and the ecological conditions improved and their resources fully utilised. 


\section{A.G.K. MENON \& K. RAMAN}

\section{REFERENCES}

CHACKO, P.I. et al 1953. Report on a survey of the flora fauna and fisheries of the Pulicat Lake, Madras State, India, 195152. Contr. Fresh W. Fish. Biol. Stn., No. 8: 20.

RAO, B.S.R. and NARASIMHAN 1971. Some aspects of the geochemistry and sedimentology of the Pulicat lake, India (Ph.D. thesis of Sri Venkateswara University, Tirupati).

SREENIVASAN, A. and K.V.N. PlLLAY 1972. Hydrology of Pulicat lake. Proceedings of Seminar on Mariculture and mechanised fishing, Govt. of Tamil Nadu, Madras: 60-66.

TAMPI, P.R.S. 1959. The ecology and fisheries characteristics of salt water lagoon near Mandapam, J. Mar. Biol. Sur. India, 1 (2): 114-130. 